Urgent talks follow damning report on
US weapons labs

[WASHINGTON] The US Department of Energy and congressional allies of its troubled nuclear weapons laboratories are this week seeking to hammer out a compromise for their future administration. They are keen to deflect growing pressure for drastic change, following the release of a scathing report on security at the laboratories.

The report, Science at its Best, Security at its Worst, was issued last week by the President's Foreign Intelligence Advisory Board (PFIAB), chaired by a former Republican senator, Warren Rudman. The report "struck quite a nerve" in the administration, according to one official there, by the intensity of its criticism of the energy department's management of the laboratories.

Even more troubling for the administration was the board's recommendation that the labs should be split off from the main structure of the department and placed in a semiautonomous agency within the department.

Lab supporters had earlier blocked a drive by Republicans to move all nuclear weapons research into the defence department and end visits to the labs by foreign scientists.

But the Rudman report has revived pressure for administrative reforms. Senator Pete Domenici (Republican, New Mexico), a leading supporter of the labs, has come out in favour of Rudman's proposal for an Agency for Nuclear Stewardship within the energy department. It would be similar in concept to the National Oceanographic and Atmospheric Agency within the Department of Commerce.

At first, Bill Richardson, the energy secretary, called the plan unworkable. "The security problems at the department are broader than the board recognizes," he said. A new agency would "erode the link between national security and science at its best".

But by last weekend Richardson was said to be backing down and a compromise with Domenici was in the works. One option was to create an undersecretary for weapons and security in the energy department. But such a move could be construed as adding another layer of the administrative complexity which Rudman roundly criticized. The issue was due to be addressed this week at joint hearings of four congressional committees.

Meanwhile, developments unfolded in the investigation of security violations at the Los Alamos National Laboratory, New Mexico. The Albuquerque Journal reported that the inquiry was extending considerably beyond Wen Ho Lee, the scientist whose alleged security violations triggered the lab scandal. On Monday (21 June), Richardson said that polygraph testing was to begin this week on up to 5,000 weapons lab staff.

Willepkowski

\title{
Varmus defends plan for global biomedical e-journal
}

[WASHINGTON] Harold Varmus, director of the US National Institutes of Health (NIH), has responded to critics of his plan for a global website centralizing biomedical literature, arguing for example that it would not threaten traditional journals.

In a seven-page message posted on the NIH's website on Monday (21 June), Varmus says that 'E-Biomed' would give "free, fast and full access" to the entire biomedical research literature for anyone with a computer and an Internet connection.

And, while accepting that the cost and mechanism of paying for the site are undetermined, he suggests that financing could come from fees levied on authors.

Varmus's retort to his critics follows the NIH's receipt of more than 200 responses to the proposal (see Nature 398, 735; 1999 \& $399,8-9 ; 1999)$. The NIH director wants to create an "electronic public library of medicine" containing peer-reviewed and nonpeer-reviewed literature.

Many journals see the proposal as threatening their existence. But Varmus stresses that 'E-Biomed' should "in no sense be interpreted as a proposal to interfere with, control or restrict journals". The NIH is eager to encourage journals, especially top-tier ones, "to become part of the ['E-Biomed'] system".

$\mathrm{He}$ also calls concerns that 'E-Biomed' represents a power grab by the federal government an "unfortunate misreading". The site, he writes, "would not be owned by the NIH or any other component of the US government". The agency's role would be limited to "technical assistance and financial support".

Varmus challenges the worries of scientific societies that they would be driven into poverty by the loss of subscriptions, counselling them to raise membership fees and conduct workshops to generate new income.

And he downplays concerns about the non-peer-reviewed section of 'E-Biomed'. Critics have said that unreviewed clinical papers could endanger public safety, and that unreviewed work would erode the line between rigorous and 'junk' science. Few scientists would publish the latter, says Varmus, because of concern for their reputations. And clinical worries are "misplaced" because readers will be clearly informed about which reports have been peer-reviewed.

But Varmus's response drew a negative reception from several critics. "It's a pipe dream to think I can double dues" to recover lost subscription income, says Martin Frank, executive director of the American Physiological Society, which publishes 14 journals.

Jerome Kassirer, editor-in-chief of the New England Journal of Medicine, is still concerned about the non-peer-reviewed section. "It contaminates the literature," he says, adding that, in the case of clinical studies, it potentially endangers the public, whom he does not believe are adept at discriminating between dubious material and solid science.

But Michael Cox, a professor of biochemistry at the University of Wisconsin-Madison, who wrote to Varmus last month calling 'EBiomed' "among the worst ideas I have ever heard," says he is somewhat mollified by the $\mathrm{NIH}$ director's retort. "The people putting this together are thinking about [scientists' and journals'] major concerns," says Cox.

Varmus's statement can be found on the web at www.nih.gov/welcome/director/ ebiomed/ebiomed.htm MeredithWadman

\section{One-stop shop for 200 life science journals}

[PARIS] The American Institute

of Biological Sciences has announced plans to combine up to 200 of the journals published by its member societies within a single, searchable website. A prototype version of 'BioOne', as it is called, is scheduled to be launched in 2001.

The institute's 55 members include the American Museum of Natural History and the Botanical Society of America. BioOne is supported by a consortium made up of the institute and the Scholarly Publishing and
Academic Resources Coalition (SPARC), the University of Kansas, the publisher Allen Press, and the 'Big 12 Plus Libraries Consortium', which groups 23 US research libraries.

The move is a dramatic example of a trend towards aggregation of titles on the web that is being driven by user demand for 'one-stop shopping', the capacity to search a wide literature from a handful of gateways.

BioOne also intends to digitize and make available back issues of journals, and is keen to include journals published by non-members of the institute. It is the latest in a series of initiatives by SPARC and US universities to put pressure on the publishers of expensive journals by offering competitive web publishing services at reduced prices (Nature 397, 195-200; 1999).

BioOne's goal is to help learned societies and the publishers of inexpensive journals to establish a presence on the web by combining expertise and infrastructure. Declan Butler 